\title{
Self-sealing of unsealed aluminium anodic oxide films in very different atmospheres
}

\author{
J.A. González*, M. Morcillo*, E. Escudero*, V. López", A. Bautista*a and E. Otero*
}

Abstract It widely believed that the corrosion resistance behaviour of bare aluminium in natural
environments is superior to that of unsealed anodised aluminium. However, results
obtained in the exposure of unsealed anodised aluminium specimens with three different
film thicknesses, in 9 atmospheres of Ibero-America with salinity levels between 3.9 and
$517 \mathrm{mg} \cdot \mathrm{m}^{-2} \cdot \mathrm{d}^{-1}$ chloride, clearly shows the reverse to be true. After a sufficient time, which
is shorter the higher the precipitation rate and the environmental relative humidity, a self-
sealing process takes place, leading to coatings that surpass the quality standards demanded
in industrial practice. Anodic films, sealed and unsealed, are protective coatings whose
quality improves with ageing in most natural environments.

Keywords Aluminium. Anodising. Sealed specimens. Unsealed specimens. Selfsealing.

\section{Autosellado de las capas anódicas del aluminio en atmósferas muy diferentes}

\begin{abstract}
Resumen Está muy difundida la idea de que el comportamiento del aluminio es superior al del aluminio anodizado y sin sellar, desde el punto de vista de la resistencia a la corrosión, en los ambientes naturales. Sin embargo, los resultados obtenidos en la exposición de anodizados sin sellar, de tres espesores diferentes, a 9 atmósferas de Iberoamérica, con salinidades comprendidas entre 3,9 y $517 \mathrm{mg} \cdot \mathrm{m}^{-2} \cdot \mathrm{d}^{-1}$ de cloruros, muestran, sin lugar a dudas, lo contrario. Con tiempo suficiente, tanto más rápidamente cuanto mayor sean las precipitaciones y la humedad relativa ambiental, tiene lugar un proceso de autosellado que conduce a recubrimientos que superan las normas de calidad exigidas en la práctica industrial. Los anodizados, sellados y sin sellar, son recubrimientos protectores que mejoran su calidad, en la mayoría de los ambientes naturales, con el envejecimiento.
\end{abstract}

Palabras clave Aluminio. Anodizado. Probetas selladas. Probetas sin sellar. Autosellado.

\section{INTRODUCTION}

No metallic materials can currently compete, on a cost for cost basis, with aluminium and its alloys, in terms of atmospheric corrosion resistance and decorative properties. These characteristics can furthermore be greatly improved by means of anodising, sealing and colouring treatments ${ }^{[1]}$.

The application of aluminium in interior and exterior architectural elements dates from the 1890's, in historic cases such as the church of Saint Gioacchino in Rome which have just reached a century of age ${ }^{[2]}$, and it may be considered to be "the newest of old construction materials, or the oldest of new materials" ${ }^{\prime[3]}$. Anodised aluminium was first used in the 1930's in several public buildings in the United Kingdom ${ }^{[3]}$, which continue to present a good state of conservation.

The excellent corrosion resistance of aluminium alloys in natural environments guarantees the permanence of their physical and functional characteristics. However, a progressive loss of shine or darkening, accompanied by a characteristic simple spotting in atmospheres of low aggressivity or localised corrosion in marine or industrial environments, can seriously affect their appearance, and in architecture, technical and decorative characteristics are often of similar importance.

The hardness of anodic films, much greater than that of the bare metal, provides protection against

(*) Centro Nacional de Investigaciones Metalúrgicas (CENIM), (CSIC), Avda. Gregorio del Amo, 8. 28040 Madrid (España). 
abrasion, correcting one of this material's few defects, enormously facilitating maintenance and cleaning operations and thereby the permanence of their attractive appearance. This explains the industrial popularity of anodising, particularly since the commencement of industrial sealing operations some 70 years ago ${ }^{[4]}$. However, the porous structure of anodic layers, a feature that represents their most appreciated quality, due to their capacity to adopt different colourings, is also contradictorily their most feared limitation, as their high adsorbent capacity facilitates soiling and the penetration of aggressive agents in the pore network. This makes it necessary to plug the pores by means of an industrial sealing operation, which is traditionally carried out in boiling deionised water for $2-3$ min per $\mu \mathrm{m}$ of thickness ${ }^{[5]}$.

The above situation explains why it is commonly believed that the behaviour of bare aluminium is better than that of unsealed anodised aluminium, from the point of view of corrosion resistance, in natural environments. The present research aims to establish to what degree this belief is technically and scientifically fundamented, and involves the exposure of unsealed anodic coatings, of 3 different thicknesses, in different atmospheric testing stations in Ibero-America covering a wide range of climatological and contamination conditions.

\section{EXPERIMENTAL}

Aluminium specimens of commercial purity $(99.5 \%$ $\mathrm{Al})$ were exposed in the natural testing stations of the Ibero-American PATINA project ${ }^{[6]}$, listed in table $\mathrm{I}$ in order of increasing chloride contamination. The specimens were previously anodised in industrial conditions (sulphuric acid solution $18 \%$ by weight, at $20^{\circ} \mathrm{C}$ and $1.5 \mathrm{~A} / \mathrm{dm}^{2}$ ). Anodising was carried out for different times, giving anodic layers of 7,17 and $20 \mu \mathrm{m}$, approx., thus covering the margin of thicknesses usual in architectural applications. During the course of the research use was made of gravimetric and electrochemical techniques, as well as standard sealing quality control tests and, occasionally, optical and scanning electron microscopy. Impedance measurements were made in an unstirred, aerated 3,5\% $\mathrm{K}_{2} \mathrm{SO}_{4}$ solution at room temperature, over the frequency range from 100 $\mathrm{kHz}$ to $1 \mathrm{mHz}$ under controlled potential conditions, with an AC potential signal of $5 \mathrm{mV}$ varied about the open circuit potential. The
Table $\mathrm{I} . \mathrm{Cl}^{-}$contamination grade in the test stations, electrochemical parameters and sealing quality results of anodic layers after 9-10 months of atmospheric exposure

Tabla l. Grado de contaminación en $\mathrm{Cl}$ de las estaciones de ensayo, parámetros electroquímicos y calidad del sellado de las capas anódicas, después de 9-10 meses de exposición atmosférica

\begin{tabular}{|c|c|c|c|c|c|c|}
\hline STATION & $\begin{array}{c}\mathrm{Cl}^{-} \\
\mathrm{mg} / \mathrm{m}^{2} \mathrm{~d}\end{array}$ & $\begin{array}{c}R_{p} \\
K \Omega \mathrm{cm}^{2}\end{array}$ & $\begin{array}{l}C_{p} \\
n F\end{array}$ & $\begin{array}{l}C_{b} \\
\mu F\end{array}$ & D.S. & $\begin{array}{c}Y \\
\mu S\end{array}$ \\
\hline PARDO $1 *$ & & 3.7 & - & 1.35 & 1.5 & 98 \\
\hline PARDO2 & 2.7 & 31.5 & - & 0.56 & 2.5 & 240 \\
\hline PARDO3 & & 11.5 & - & 0.52 & 3.5 & $>300$ \\
\hline MADRID1 & & 14.8 & - & 1.36 & 1.5 & $>300$ \\
\hline MADRID2 & Traces & 400 & 50 & 0.60 & 3 & $>300$ \\
\hline MADRID3 & & 400 & 27 & 0.51 & 4 & 230 \\
\hline PANAMA1 & & 1400 & 11.5 & 0.58 & 0 & 5 \\
\hline PANAMA2 & 9.8 & 1200 & 3.6 & 0.33 & 1.5 & 13 \\
\hline PANAMA3 & & 670 & 8.09 & 0.55 & 3 & 47 \\
\hline LUMIAR1 & & 18.3 & - & 0.97 & 3 & $>300$ \\
\hline LUMIAR2 & 19.6 & 28.9 & 128 & 0.58 & 4 & 300 \\
\hline LUMIAR3 & & 47.1 & 128 & 1.18 & 4 & $>300$ \\
\hline LIMA1 & & 101 & 14.0 & 1.20 & 1 & 20 \\
\hline LIMA2 & 54.9 & 275 & 5.1 & 0.53 & 2 & 17 \\
\hline LIMA3 & & 208 & 7.4 & 0.96 & 3 & 27 \\
\hline COJIMAR1 & & 34.4 & 20 & 0.64 & 0.5 & 42 \\
\hline COJIMAR2 & 112 & 5.6 & - & 1.44 & 2 & 212 \\
\hline COJIMAR3 & & 20.9 & 40 & 0.83 & 3 & 112 \\
\hline PUNTA ESTE1 & & 9.4 & - & 1.15 & 1 & 67 \\
\hline PUNTA ESTE2 & 163 & 20.5 & - & 2.15 & 2 & 47 \\
\hline PUNTA ESTE3 & & 79 & 34.5 & 0.60 & 3 & 64 \\
\hline VIRIATO1 & & 46.3 & 71 & 1.48 & 1.5 & 17 \\
\hline VIRIATO2 & 368 & 20.7 & - & 1.34 & 0.5 & 74 \\
\hline VIRIATO3 & & 50 & 47 & 0.55 & 2.5 & 120 \\
\hline
\end{tabular}

* Numbers 1, 2 and 3 refer, respectively, to thicknesses of 7,17 and $28 \mu \mathrm{m}$.

$\mathrm{Cl}^{-}$-Contamination grade

$R_{p} \quad$-Resistance of the porous layer

$C_{p}$-Capacitance of the porous layer

$C_{b}$-Capacitance of the barrier layer

D.S. -Dye Spot

$Y$-Admitance

electronic equipment consisted of a PAR model 273A potentiostat and a Solartron 1250 frequency response analyser remotely controlled by a computer.

The exposure times considered were short, 10 and 16 months, though any failure of the unsealed anodic coatings should occur quickly, before the rain or any other type of precipitation can promote slow, natural self-sealing at environmental temperature. For comparative purposes, data was 
also considered for bare aluminium specimens and sealed anodic films of the same thicknesses which had been exposed in the same testing stations during the PATINA project ${ }^{[6]}$.

\section{EXPERIMENTAL RESULTS}

Figure 1 illustrates the mass variations experienced by the unsealed anodic coatings, for the 3 thicknesses considered, after 10 months of exposure in the different testing stations. The figure also indicates the variations that take place during 60 min of sealing in boiling deionised water.

Bare aluminium is prone to suffer pitting or blistering during the first year of atmospheric exposure for chloride pollution over $50 \mathrm{mg} \cdot \mathrm{m}^{-2} \cdot \mathrm{d}^{-1}$ (Fig. 2a). However, sealed and unsealed anodic films avoid the risk of blistering and pitting corrosion (Fig. 2b), except with the lowest film tickness and very high atmospheric aggressiveness.

If the barrier and porous layers of the anodic films are in perfect state, the equivalent circuits (EC) of figures $3 \mathrm{a}$ and $3 \mathrm{~b}$ simulate with sufficient approximation the responses of correctly sealed and unsealed anodized surfaces, respectively ${ }^{[7}$ and 8$]$, whose impedance diagrams are shown in figure 3c. A schematic indication is also given of the way of approximately estimating the electrochemical

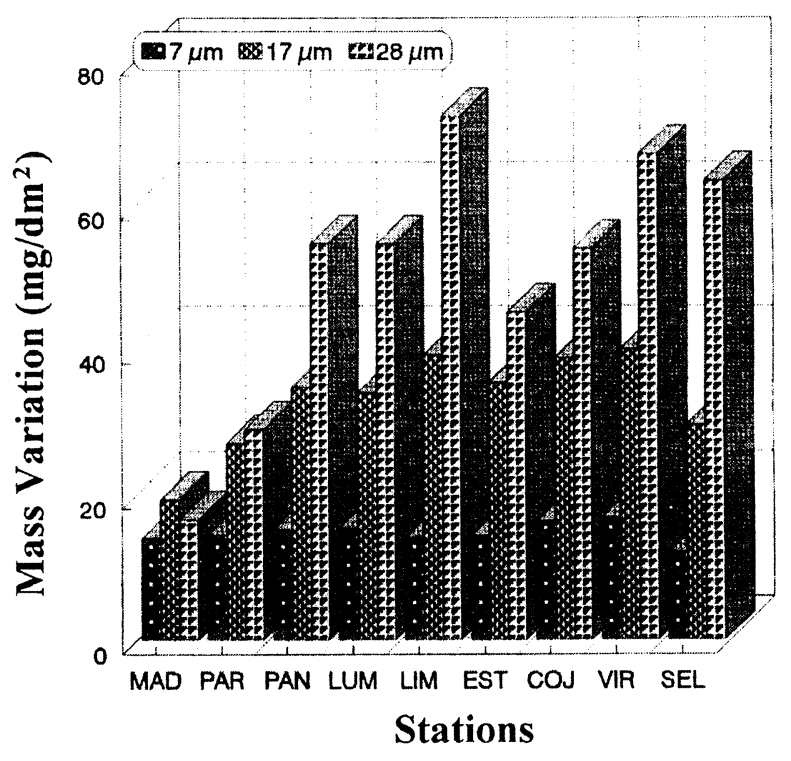

Figure 1. Mass variations as a function of time and anodic film thickness. The stations are listed in order of increasing salinity.

Figura 1. Variaciones de masa en función del tiempo y del espesor de anodizado. Las estaciones están situadas por orden de salinidad creciente.
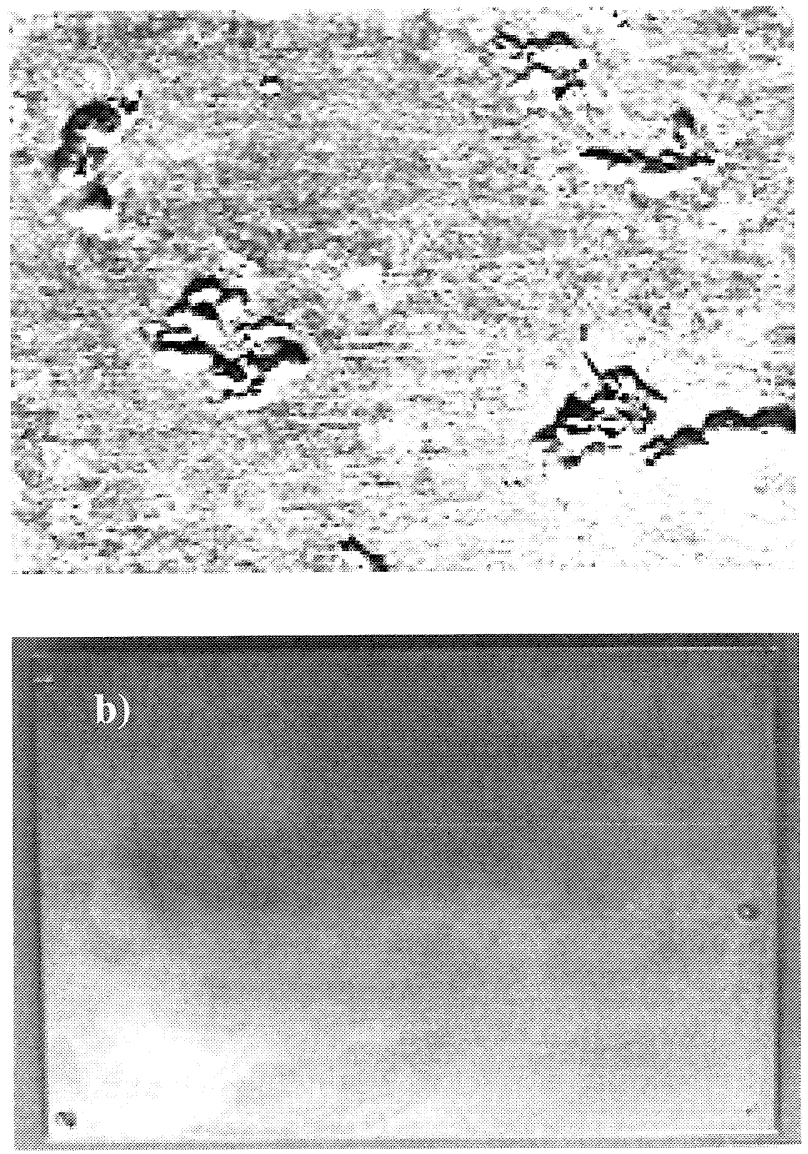

Figure 2. Localised corrosion of bare Al specimens exposed during a year in Lima atmosphere (a). Sealed or unsealed anodic films of 17 and $28 \mu \mathrm{m}$ avoid the risk of blistering and pitting corrosion (b).

Figura 2. Corrosión localizada del aluminio desnudo expuesto durante 1 año en la atmósfera de Lima (a). Capas anódicas sellada o sin sellar de 17 y 28 m de espesor evitan el riesgo de ampollamiento y corrosión por picaduras (b).

parameters of the coatings. In figures $3 a$ and $3 b, R_{p}$ and $C_{p}$ represent the resistance and capacitance of the porous layer; $C_{b}$ the capacitance of the barrier layer and $R_{\text {sol }}$ the resistance of the electrolyte, which in most cases may be ignored without appreciable error. A schematic indication is also given of the way of approximately estimating the electrochemical parameters of the coatings.

Figures 4 and 5 display diagrams obtained for the 3 anodic film thicknesses in El Pardo and Lima stations, respectively, after 10 months of exposure. These are situations with very different degrees of self-sealing (water absorption), very low in the former and high in the latter. In both cases the curve corresponding to an unsealed anodic film immediately after its obtainment is also included, in order to facilitate visual appreciation of the degree of self-sealing. 

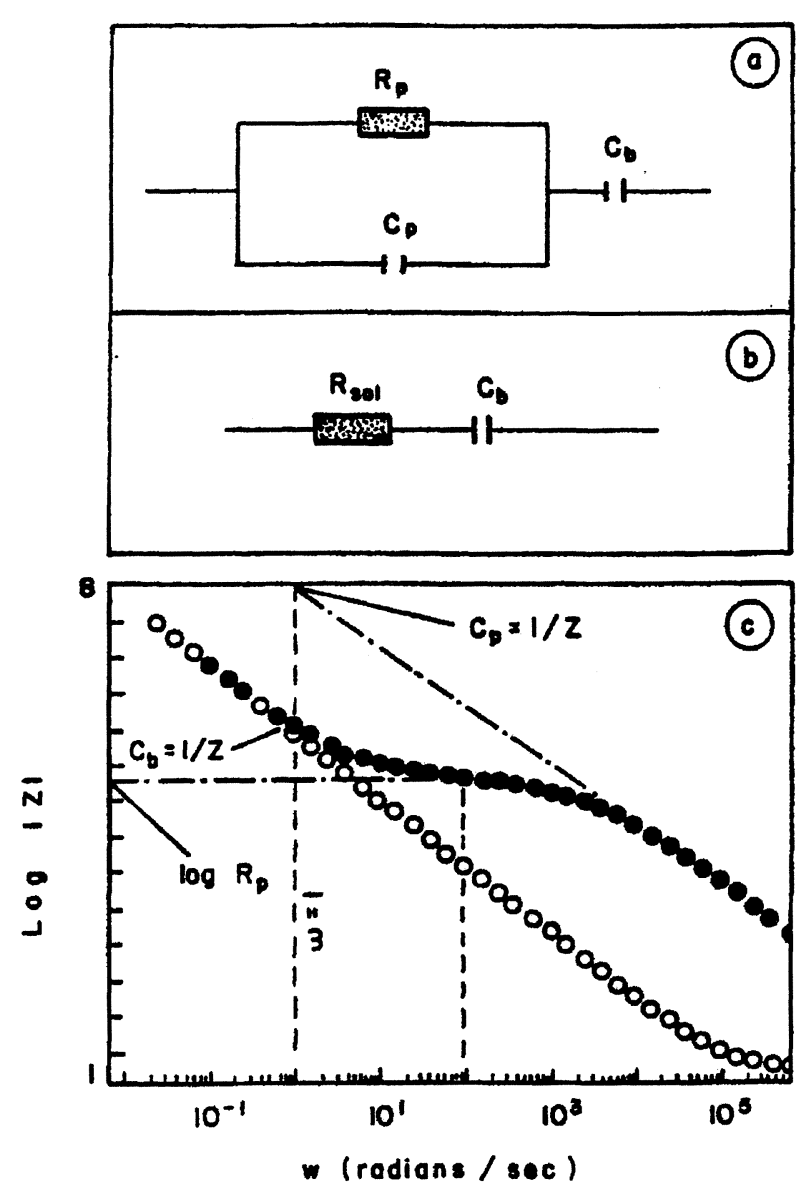

Figure 3. Simplified equivalent circuits for sealed (a) and unsealed (b) films and Bode diagrams corresponding to anodic films of $20 \mu \mathrm{m}(\mathrm{c})$, unsealed (O) and correctly sealed (०).

Figura 3. Circuitos equivalentes simplificados para anodizados sellados (a) y sin sellar (b) y diagramas de Bode correspondientes a un anodizado de $20 \mu \mathrm{m}(\mathrm{c})$, sin sellar (O) y correctamente sellado (O).

From impedance diagrams, such as those in figures 3,4 and 5 , it is possible to estimate the physical-chemical characteristics of the coatings which define their integrity and quality. Table I shows parameters of this type, specifically the resistance and capacitance of the porous layer, $R_{p}$ and $\mathrm{C}_{\mathrm{p}}$, when a minimum degree of self-sealing allows these to be calculated, and the capacitance of the barrier layer, $\mathrm{C}_{\mathrm{b}}$. The table also includes the results of dye spot tests and admittance at $1 \mathrm{kHz}$, used in industrial practice to routinely measure anodic layers ${ }^{[9]}$.

Figure 6, which compares the diagrams for a specimen at the end of exposure in El Pardo station, after a further 5 months of ageing in the laboratory atmosphere, and at the end of an additional period of 2 months in the humidity cabinet $(\mathrm{RH} \approx 95 \%)$, serves as proof that the self-

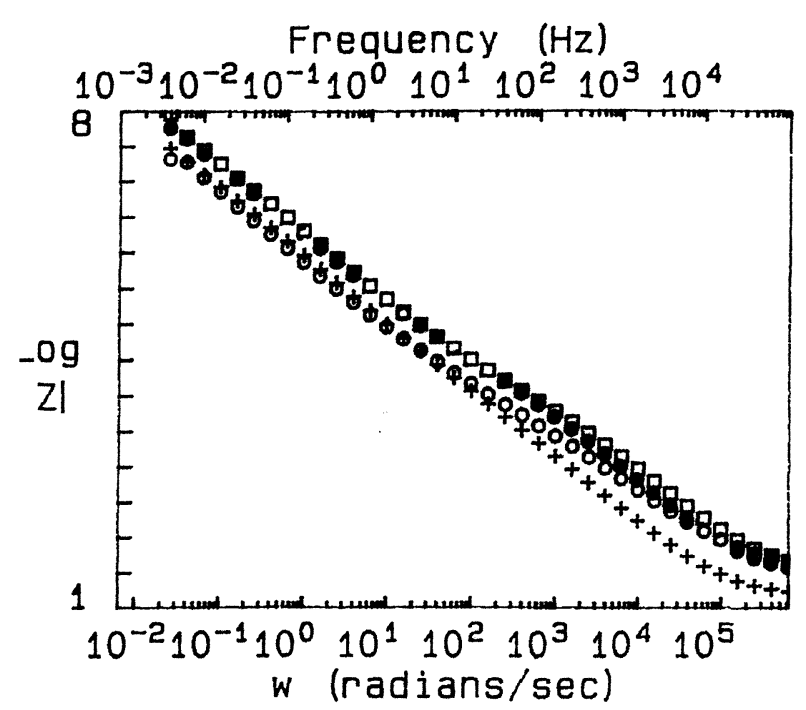

Figure 4. Unsealed anodic films of $7(0), 17(0)$ and $28 \mu \mathrm{m}$ $(\square)$ exposed in El Pardo.The symbol $(+)$ corresponds to an unsealed anodic film prior to the start of exposure.

Figura 4. Diagramas de Bode correspondientes a anodizados sin sellar de 7 (0), 17 (0) y $28 \mu \mathrm{m}(\square)$ expuestos en El Pardo. El símbolo (+) corresponde a un anodizado sin sellar antes de iniciar la exposición.

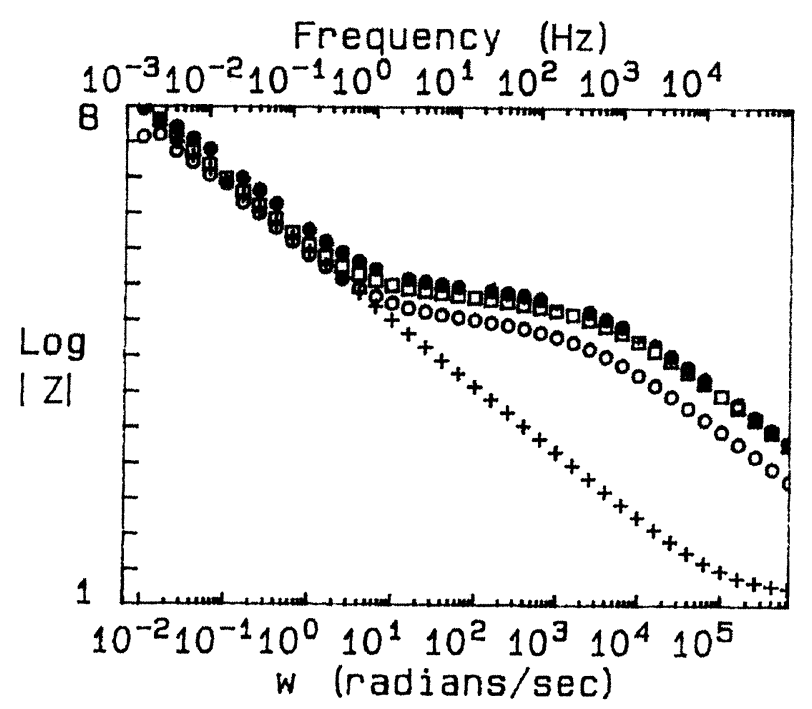

Figure 5. Unsealed anodic films of $7(0), 17(0)$ and $28 \mu \mathrm{m}$ ( $\square$ ) exposed in Lima.The symbol $(+)$ corresponds to an unsealed anodic film prior to the start of exposure.

Figura 5. Diagramas de Bode correspondientes a anodizados sin sellar de $7(O), 17(\bullet)$ y $28 \mu \mathrm{m}(\square)$ expuestos en Lima. El símbolo (+) corresponde a un anodizado sin sellar antes de iniciar la exposición.

sealing capacity remains for as long as the pores are not saturated.

Finally, figure 7 represents the variations caused by the ageing of unsealed anodic layers subjected in the laboratory to a very humid atmosphere of 


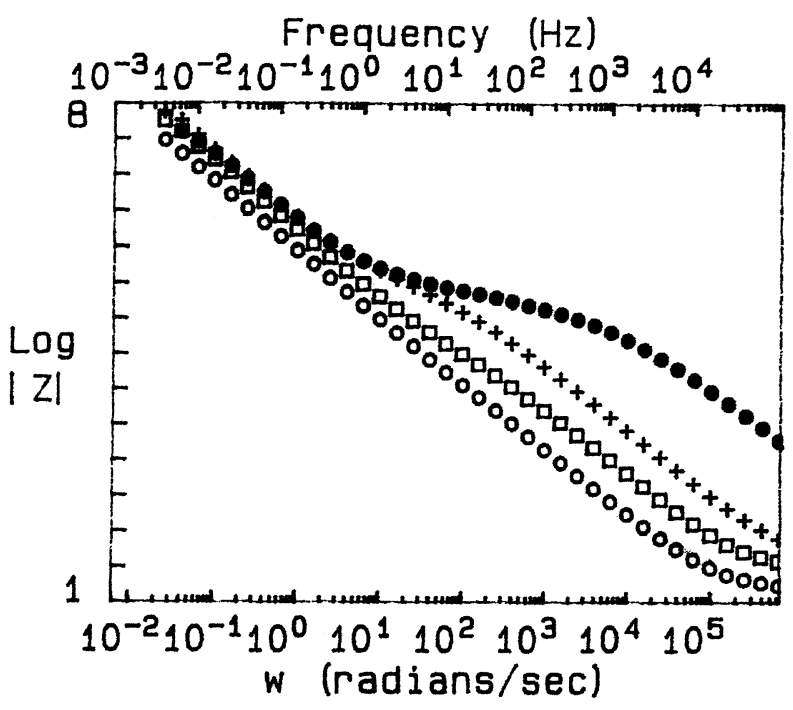

Figure 6. Bode diagrams for unsealed $17 \mu \mathrm{m}$ anodic films: recently obtained (O), after exposure in El Pardo testing station ( $\square$ ), after 5 further months of ageing in the dry laboratory atmosphere $(+)$ and after 2 additional months in a humidity cabinet (0).

Figura 6. Diagramas de Bode de anodizados de $17 \mu \mathrm{m}$ sin sellar: recién obtenido (O), después de la exposición en la estación de El Pardo ( $\square$ ), después de 5 meses adicionales de envejecimiento en la atmósfera seca del laboratorio $(+)$ y al término de 2 meses más de permanencia en cámara húmeda (O).

approximately $95 \% \mathrm{RH}$, covering a somewhat longer time. The figure again shows the versatility

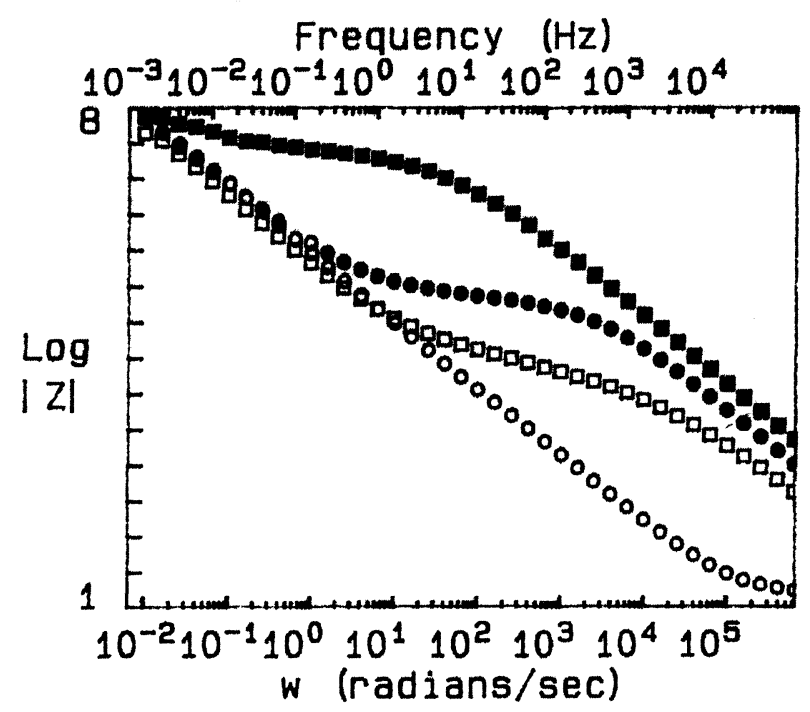

Figure 7. Unsealed anodic films of $20 \mu \mathrm{m}$ thickness: recently obtained (O), and after 30 days $(\square) 100$ days (O) and 5 years of exposure in a humidity cabinet $(\approx 95 \% \mathrm{RH})(\square)$.

Figura 7. Diagramas de Bode de anodizados sin sellar de $20 \mu \mathrm{m}$ de espesor recién obtenidos (O), y después de 30 dias ( $\square$ ), 100 días (0) y 5 años de permanencia en una cámara húmeda $(\approx 95 \% R H)(\square)$ of EIS (Electrochemical Impedance Spectroscopy) for appreciating the modifications in anodic films due to ageing or, presumably, those due to any other factor affecting their quality.

\section{DISCUSSION}

In atmospheres of low or moderate aggressivity the corrosion resistance of unsealed anodic films, their durability, is so high that no symptom of corrosion is appreciated for sufficient coating thicknesses (Fig. 2b), while the appearance is significantly affected in the case of bare $\mathrm{Al}$ (Fig. 2a) and somewhat in the case of anodic films of low thickness in strongly polluted atmospheres.

In any case, corrosion processes in anodic films are so limited, in terms of magnitude, that they are not reflected gravimetrically. In fact, the mass variations recorded are highly similar to the absorption of water during sealing, which is proportional to the anodic film thickness (Fig. 1), in humid environments such as Lima and Viriato, indicating that they can be attributed to water absorption, until the saturation of the pores, in a slow self-sealing process and not to a corrosion phenomenon. Where precipitation is scarce and the environmental relative humidity is so low that the dew point is only occasionally reached, the mass gain is not proportional to the film thickness (El Pardo), or is independent of this (Madrid), indicating that the pores are not filled in anodic films of 17 and $28 \mu \mathrm{m}$ (Fig. 1). In these cases, selfsealing processes are hindered and delayed until the climatology is favourable, and this is reflected in highly different impedance diagrams, typical of unsealed anodic films in dry climates and sealed anodic films in humid climates, figures 4 and 5 , respectively. Electrochemical impedance spectroscopy (EIS) and gravimetry offer different aspects of the same reality, but their results are mutually confirming and lead to identical conclusions.

On the other hand, as the field of variability of the impedance is $2-3$ orders of magnitude, between unsealed and correctly. sealed aluminium (Fig. 3), EIS is a tool of extraordinary sensitivity for discerning the quality of the seal. With the progress of the hydration reactions in the interior of the pores, $R_{p}$ increases and $C_{p}$ decreases, and in a simplified way it can be considered that the quality of the anodic films is better the greater the $R_{p}$ and the lower the $C_{p}{ }^{[1]}$. The values of both parameters can be used as quantitative indices to analyse the 
effect of any factor on the characteristics of anodic layers of aluminium oxide, their state, or their presumable response in a particular environment.

Fortunately, the passage of time does not destroy the self-sealing capacity, as can be seen in the impedance diagrams in figure 6 , with an increase in the quality of the anodic films (their protective capacity). This can be quantified through the increase in the resistance of the porous layer, $R_{p}$, shown by the almost horizontal section of the impedance diagrams ${ }^{[7,8 \text { and } 10]}$. EIS is also seen to be an appropriate tool for evaluating phenomena such as the the degree of self-sealing (Figs. 4 and 5) and the degree of ageing (Figs. 6 and 7).

Standard sealing quality control tests offer another convenient way of checking the effects of exposure on unsealed anodic coatings, through the reduction in absorbent capacity with the filling of the pores (dye spot test), or the reduction in conductivity with the blocking of the pores (measurement of admittance at $1 \mathrm{kHz})^{[9]}$. Industrial practice accepts dye spot intensities of $\leq 2$, on a scale from 0 to 5 , or admittances of $\leq 20$ (for anodic films of $20 \mu \mathrm{m}$ thickness) ${ }^{[9]}$. Table I shows that, in concordance with the impedance diagrams of figures 4 and 5 , self-sealing has surpassed the demanded quality thresholds in Lima station for the thicknesses of 7 and $17 \mu \mathrm{m}$, while it has only just reached these levels in the case of the $7 \mu \mathrm{m}$ thickness, the only one in which the pores are filled, in the dye spot tests in El Pardo and Madrid stations.

\section{Acknowledgements}

The authors wish to thank S. Flores (Peru), E. Almeida (Portugal), M. Sánchez (Panama), J. Peña (Ecuador), M. Marrocos (Brazil), S. Rivero (Uruguay), O.T. Rincón (Venezuela), F. Corvo (Cuba) and B. Rosales (Argentina) for exposing the materials in their test stations.

\section{REFERENCES}

[1] R. Lizarbe, V. López, E. Otero and J.A. GonzÁlez, Rev. Metal. Madrid. 26 (1990) 359-367.

[2] F. Gatto and A. Perrone, Alluminio. Sept. (1981) 434444.

[3] E.W. SKerreY, Atmospheric corrosion, Ed. W.H. Ailor. John Wiley and Sons, New York, 1982, pp. 329-352.

[4] H. RöHRIG, Z. Elektrochem. 37 (1931) 721.

[5] R. LizARBE, Teoría y práctica de la lucha contra la corrosión, Coord. González, J.A., Ed. CSIC, Madrid, 1984, Capítulo 16, pp. 461-484.

[6] J.A. González, M. Morcillo, A. Bautista, F. Corvo and J. Simancas, Proc. 14th Int. Corrosion Congress, Cape Town, South Africa, Sept., 1999.

[7] J. Hitzing, K. Juttner, W.J. Lorenz and W.J. PAatsch, Electrochem. Soc. 103 (1986) 887.

[8] J.A. González, E. Otero, A. Bautista and V. López, Plat. Surf. Finish. 84 (1997) 59-63.

[9] UNE 38-017, 38-018, 38-026 and 38-014, standards.

[10] V. López, E. Otero, A. Bautista and J. A. GonzÁlez, Aluminium, 74 (1998) 398-402. 